\title{
Ceftazidime: pharmacokinetics in young volunteers versus elderly patients and therapeutic efficacy with complicated urinary tract infections
}

\author{
Kurt G. Naber*, Frieder Kees† and Horst Grobecker † \\ * Urologic Clinic, Elisabeth-Krankenhaus, Schulgasse 20,8440 Straubing and \\ $\dagger$ Department of Pharmacology, University of Regensburg, Universitätsstr. 31, \\ 8400 Regensburg, West Germany
}

\begin{abstract}
Thirty-six urological patients (21 male, 15 female) aged 21 to 83 years with complicated and/or hospital-acquired urinary tract infections due to sensitive bacteria were treated with ceftazidime intravenously with a daily dose of $2 \mathrm{~g}$ bd over 5 to 17 days. Twenty-seven patients were followed for 1 to 4 weeks after therapy. Cure was observed in $41 \%$, reinfection in $33 \%$ and relapse in $26 \%$ of the patients. Eradication of the original pathogen occurred in $74 \%$. Five patients showed minor side effects: diarrhoea (2), nausea (1), rash (1), headache (1). No signs of renal, hepatic or haematological toxicity were observed.

A pharmacokinetic study was performed in 13 elderly patients aged 63 to 83 years on day 1 of treatment and in 6 volunteers aged 24 to 32 years following administration of $2 \mathrm{~g}$ of ceftazidime as short intravenous infusion. The mean serum half life in 12 patients $2.9 \mathrm{~h}$ significantly higher than in volunteers $(1.75 \mathrm{~h})$. Serum concentrations in patients on day 7 of treatment, however, showed no accumulation when treated with a dosage of $2 \mathrm{~g}$ bd.
\end{abstract}

\section{Introduction}

Ceftazidime is currently used in the treatment of complicated urinary tract infections because of its broad-spectrum antibacterial activity especially against Gram-negative bacteria including Pseudomonas spp. (Harper, 1981). Its pharmacokinetic properties include a terminal serum half life of approximately $1.8 \mathrm{~h}$, renal excretion by glomerular filtration with an $88 \%$ urinary recovery in $24 \mathrm{~h}$ and a low protein binding of about $10 \%$. No metabolites are found in serum or urine (Harding et al., 1981). In the present study the therapeutic efficacy with complicated and/or hospital-acquired urinary tract infections in urological patients and the pharmacokinetic parameters in elderly patients as compared to young volunteers were evaluated.

\section{Materials and methods}

A total of 36 urological patients (21 male, 15 female) aged 21 to 83 years (median 77 years) with complicated and/or hospital acquired urinary tract infections (defined as colony counts $\geqq 10^{3} / \mathrm{ml}$ ) were treated with ceftazidime $2 \mathrm{~g}$ bd by short intravenous infusion over 5 to 17 days (median 8 ). Three of these patients ( 2 male, 1 female) had moderate renal insufficiency (serum creatinine 1.7 to $2.4 \mathrm{mg} / \mathrm{dl}$ ). In one male patient aged 77 years the therapy was discontinued after 2 days because of nausea. Thirteen of the 21 male patients had an indwelling catheter. In 9 patients a catheter was used transiently 
( 2 to 12 days, median 4). Only in 3 patients could the catheter not be removed before or during therapy.

Midstream or catheter urine in males and catheter urine in females, was collected before, during, 1 to 6 days and again 1 to 4 weeks after the end of therapy. Counting and identification of isolates was performed by standard methods and the API-20 system. Agar susceptibility of bacteria was determined by an agar-diffusion method according to ICS recommendations with Mueller-Hinton agar (Merck) and $10 \mu \mathrm{g}$ discs (diameter $6 \mathrm{~mm}$ ) of ceftazidime. Organisms with a zone diameter of $17 \mathrm{~mm}$ and more were classified as sensitive, corresponding to an MIC of $\leqslant 16 \mathrm{mg} / 1$ (Grimm, 1981).

The therapeutic results were determined according to the bacteriological findings, since most of the patients had no clinical symptoms. Only six patients had febrile episodes prior to therapy. Cure was diagnosed if patients showed sterile urine or bacteruria with colony counts of less than $10^{4} / \mathrm{ml}$ during therapy and during follow up period. Since some patients could not be followed longer than 1 to 6 days after treatment, these patients were classified as provisional cures, if the above mentioned urine criteria were met during this time. These patients were not included, however, in the final assessment. Patients with colony counts of greater than $10^{5} / \mathrm{ml}$ were classified as reinfection (new species) or as relapse (same species). These criteria were divided into 'early' and 'late', when the diagnosis was confirmed during the early ( 1 to 6 days) or late ( 1 to 4 weeks) follow-up period. In order to monitor tolerance of the antibiotic before, during and after treatment, the patients' clinical course was monitored and the following tests were carried out: haemoglobin, haematocrit, differential blood count, platelet count, blood-urea nitrogen, serum creatinine, GOT, GPT, gamma GT and alkaline phosphatase. Urinalysis included quantitation of leucocytes and erythrocytes, albumin and glucose.

A pharmacokinetic study was performed following administration of $2 \mathrm{~g}$ of ceftazidime as a bolus intravenous injection in 13 (11 male, 2 female) of these 36 patients aged 63 to 83 years (median 77) with a body weight of 55 to $96 \mathrm{~kg}$ (median 71), a height of 152 to $178 \mathrm{~cm}$ (median 166) and a serum creatinine of 0.7 to $1.5 \mathrm{mg} / \mathrm{dl}$ (median 1.1 ) and in 6 younger volunteers ( 3 male, 3 female) aged 24 to 32 years (median 26) with a body weight of 54 to $81 \mathrm{~kg}$ (median 63), a height of 153 to $184 \mathrm{~cm}$ (median 169) and a serum creatinine of 0.4 to $0.9 \mathrm{mg} / \mathrm{dl}$. Venous blood samples were drawn from the contralateral arm before, and 6,15 , and $30 \mathrm{~min}$, and $\mathrm{l}, 2,3,4,6,10 \mathrm{~h}$ and, in volunteers, $12 \mathrm{~h}$ after start of administration. In addition, serum concentrations were measured on day 7 of treatment before, and 1,2 and $4 \mathrm{~h}$ after administration of $2 \mathrm{~g}$ ceftazidime intravenously. Urine was collected up to $12 \mathrm{~h}$.

Serum and urine were kept frozen at $-20^{\circ} \mathrm{C}$ until analysis by HPLC method modified according to Ayrton (1981). The pharmacokinetic parameters were calculated by Glaxo Research, Greenford, using an open two-compartment model. Statistical analysis was performed using mean $( \pm$ S.D.) values and the $t$-test, in which $P<0.05$ was taken as statistically significant.

\section{Therapeutic study}

\section{Resalts}

Thirty-five patients ( 20 male, 15 female) treated for 5 days or longer could be evaluated up to 1 to 6 days and 27 patients ( 16 male, 8 female) up to 1 to 4 weeks after the end of treatment. The bacterial species isolated before therapy are listed in Table I. All strains showed inhibition diameters of $1.7 \mathrm{~mm}$ or more and were therefore classified as sensitive. In all patients with febrile episodes the fever disappeared within 2 days. During therapy only one patient infected originally by Pseudomonas fluorescens later had urine infected 
Table I. Bacterial isolates before treatment with ceftazidime

\begin{tabular}{lcc}
\hline Bacterial species & Male & Female \\
\hline Monoinfections: & 8 & 8 \\
E. coli & 2 & 2 \\
Pr. mirabilis & 1 & - \\
Pr. vulgaris & 1 & - \\
Pr. inconstans & 3 & 1 \\
Ps. aeruginosa & 1 & - \\
Ps. fluorescens & 1 & 1 \\
Klebsiella sp. & 1 & - \\
Ent. sakazakii & 1 & - \\
Ser. marcescens & - & 1 \\
Citro. freundii & 1 & - \\
Staph. aureus & & \\
Mixed infections: & - & 2 \\
E. colit & & \\
Pr. mirabilis & 20 & 15 \\
No. of patients &
\end{tabular}

Tabłe II. Bacterial isolates during and after treatment of therapy with ceftazidime

\begin{tabular}{|c|c|c|c|c|}
\hline \multirow{2}{*}{$\begin{array}{l}\text { Bacterial species } \\
\text { Monoinfections: }\end{array}$} & \multicolumn{2}{|c|}{$\begin{array}{c}\text { Male } \\
\text { Relapse/reinfection }\end{array}$} & \multicolumn{2}{|c|}{$\begin{array}{c}\text { Female } \\
\text { Relapse/reinfection }\end{array}$} \\
\hline & & & & \\
\hline E. coli & 3 & - & 1 & 1 \\
\hline Pr. mirabilis & - & - & 1 & 1 \\
\hline Ps. aeruginosa & 1 & - & - & - \\
\hline K. pnewmoniae & - & 1 & - & - \\
\hline Str. faecalis & - & 5 & - & - \\
\hline Staph. aureus & 1 & - & - & - \\
\hline $\begin{array}{l}\text { Mixed infection: } \\
\text { Staph. awreus + } \\
\text { Str. faecalis }\end{array}$ & - & 1 & - & - \\
\hline No. of patients & 5 & 7 & 2 & 2 \\
\hline
\end{tabular}

with Streptococcus faecalis and Candida albicans. One to 6 days after therapy 2 further male patients had early reinfections with colony counts of $10^{8} / \mathrm{ml}$ (Klebsiella pneumoniae, Str. faecalis). Of the 32 patients with colony counts of less than $10^{4} / \mathrm{ml} 1$ to 6 days after treatment only 21 could be followed up to 1 to 4 weeks after treatment. Eight patients ( 4 male, 4 female) had no infection during this time, six ( 4 male, 2 female) showed reinfection (late) and 7 ( 5 male, 2 female) relapsed (late). The bacteria found during therapy and the follow-up period are listed in Table II. Serotyping of $E$. coli was not performed.

The local and systemic tolerance of ceftazidime were good as judged by clinical and laboratory tests are concerned. In one patient the treatment had to be discontinued after 2 days because of nausea. Five additional patients showed clinical side effects: nausea (1), headache (1), diarrhoea (2), rash (1) on day 4 of treatment. There were no signs of haematological, hepatic or renal toxicity. 


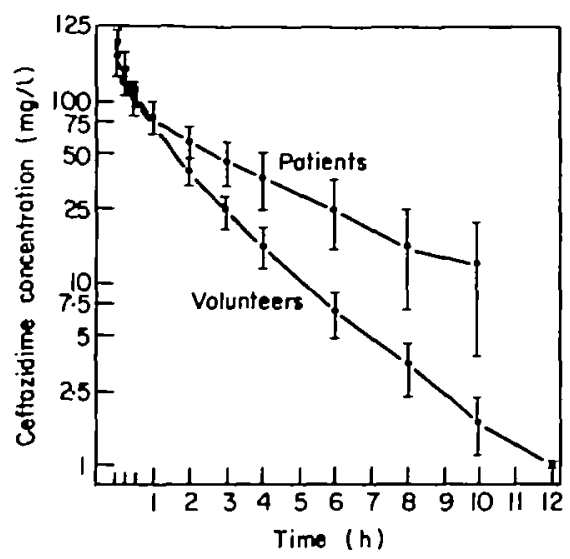

Figure 1. Mean ( \pm 8.D.) serum concentrations $(\mathrm{mg} /)$ of ceftazidime in younger volunteers $(n=6)$ aged 24 to 32 years and elderly patients $(n=13)$ aged 63 to 83 years following intravenous administration of $2 \mathrm{~g}$.

Table III. Mean ( \pm S.D.) renal excretion (\% of given dose) of ceftazidime in young volunteers $(n=6)$ and elderly patients $(n=13)$ up to $12 \mathrm{~h}$ following intravenous injection of $2 \mathrm{~g}$ of ceftazidime

$\%$ renal excretion during urine collection time (h)

\begin{tabular}{|c|c|c|c|c|}
\hline & \multicolumn{4}{|c|}{$\%$ renal excretion during urine collection time (h) } \\
\hline & $0-2$ & $2-4$ & $4-8$ & $8-12$ \\
\hline $\begin{array}{l}\text { Volunteers } \\
\text { Patients }\end{array}$ & $\begin{array}{l}59.9 \pm 4.9 \\
27.7 \pm 6.4\end{array}$ & $\begin{array}{l}75 \cdot 1 \pm 3 \cdot 5 \\
43 \cdot 4 \pm 10 \cdot 0\end{array}$ & $\begin{array}{l}83 \cdot 9 \pm 7 \cdot 9 \\
57 \cdot 3 \pm 18 \cdot 3\end{array}$ & $\begin{array}{l}86.3 \pm 8.4 \\
69 \cdot 4 \pm 11.6\end{array}$ \\
\hline
\end{tabular}

Table IV. Mean ( \pm S.D.) pharmacokinetic parameters for ceftazidime following administration of $2 \mathrm{~g}$ iv in young volunteers $(n=6)$ and elderly patients $(n=12)$ on day 1 of treatment $(2 \mathrm{~g} \mathrm{bd})$

\begin{tabular}{lcc}
\hline Parameter & Volunteers & Patients \\
\hline Serum half life (h) & $1.75 \pm 0.14$ & $2.9 \pm 0.5$ \\
Serum clearance $(\mathrm{ml} / \mathrm{min})$ & $123 \pm 11$ & $79 \pm 17$ \\
Volume of distribution & $18.9 \pm 1.5$ & $19.4 \pm 3.0$ \\
( $\%$ of body weight) & & \\
\hline
\end{tabular}

\section{Pharmacokinetic study}

Figure 1 shows the mean serum concentrations ( \pm S.D.) of the group of patients and volunteers following intravenous injection of $2 \mathrm{~g}$ of ceftazidime. The mean serum concentrations in patients (volunteers) were found to be highest at 6 min with $173 \mathrm{mg} / 1$ $(210 \mathrm{mg} / \mathrm{l})$ and fell to $76 \mathrm{mg} / 1(70 \mathrm{mg} / \mathrm{l})$ at $1 \mathrm{~h}$, to $35 \mathrm{mg} / 1(16 \mathrm{mg} /)$ at $4 \mathrm{~h}$, and to $6.7 \mathrm{mg} / 1(1.8 \mathrm{mg} / \mathrm{l})$, at $10 \mathrm{~h}$. Twelve hours after administration the mean serum concentration in volunteers was $1.0 \mathrm{mg} / \mathrm{l}$. The mean urinary excretions up to $12 \mathrm{~h}$ were in patients $69 \%$ and in volunteers $86 \%$ of the given dose (Table III). The mean serum concentrations in patients on day 1 and day 7 of treatment showed no accumulation during 1 week with this dose regimen. The pharmacokinetic parameters, serum half life, serum clearance and volume of distribution, showed a significant increase of the half life from 1.75 in volunteers to 2.9 in patients with corresponding lowering of the clearance. 
The volume of distribution was not significantly different and corresponded to the amount of extracellular fluid (Table IV). Between day 1 and day 7 of treatment there was no significant difference in the pharmacokinetic parameters calculated in the patients.

\section{Discussion}

It is often difficult to cure complicated urinary tract infections. In this study the first therapeutic aim, to control exacerbation and to prevent symptomatic infection, was achieved in all cases. The second aim, to cure complicated urinary tract infections and eradicate bacteriuria, was achieved in only $11(40 \%)$ of 27 patients followed up for 1 to 4 weeks. In these 27 patients there was a high percentage of reinfection $(33 \%)$ and relapse (26\%). Nevertheless the eradication of the original pathogen was possible in $74 \%$ of these patients. These results are in agreement with the result achieved with other broad-spectrum cephalosporins (Naber \& Bauernfeind, (1982).

In elderly patients impairment of renal function must be considered even with 'normal' serum creatinine levels (Siersbeck-Nielsen et al., 1971). This results in prolongation of serum half-lives of antibiotics excreted chiefly by the kidneys, such as cefuroxime, cefotaxime, and cefmenoxime, (Naber, 1979; Naber \& Adam, 1980; Naber et al., 1982). Although the mean serum half-life in elderly patients was twice as long as in young volunteers, no accumulation was observed during treatment over 7 days at a dosage of $2 \mathrm{~g}$ bd.

\section{References}

Ayrton, J. (1981). Assay of ceftazidime in biological fluids using high-pressure liquid chromatography. Journal of Antimicrobial Chemotherapy 8, Suppl. B, 227-31.

Grimm, H. (1981). Bacteriological investigations with ceftazidime in vitro. Journal of Antimicrobial Chemotherapy 8, Suppl. B, 213-16.

Harding, S. M., Ayrton, J., Thornton, J. E., Munro, A. J. \& Hogg, M. I. J. (1981). Pharmacokinetics of ceftazidime in normal subjects. Jowrnal of Antimicrobial Chemotherapy 8, Suppl. B, 261.

Harper, P. B. (1981). The in-vitro properties of ceftazidime, Journal of Antimicrobial Chemotherapy 8, Suppl. B, 5-13.

Naber, K. (1979). Cefuroxim: Pharmakokinetik bei geriatrischen Patienten und Therapieergebnisse beim komplizierten Harnwegsinfekt. Therapiewoche 29, 5944-53.

Naber, K. \& Adam, D. (1980). Pharmakokinetik von Cefotaxim bei geriatrischen Patienten. Münchner Medizinische Wochenschrift 122, 1651-4.

Naber, K. \& Bauernfeind, A. (1982). Behandlung des komplizierten Harnwegsinfektes mit parenteralen Cephalosporinen. Fortschritte der Antimikrobiellen \& Antineoplastischen Chemotherapie 1, 229-35.

Naber, K., Adam, D., Kees, F., Lintz, W. \& Grobecker, H. (1982). Cefmenoxim: Pharmakokinetik bei jūngeren Probanden gegenūber ālteren Patienten und Gewebekonzentrationen im Urogenitaltrakt. Fortschritte der Antimikrobiellen \& Antineoplastischen Chemotherapie 3, (in press).

Siersbeek-Nielsen, K., Hansen, J. M. \& Kampmann, J., Kristensen, M. (1971). Rapid evolution of creatinine clearance. Lancet (1971/1), 1133-4. 